\title{
Power dissipation analysis of PV module under partial shading
}

\author{
Byunggyu Yu' ${ }^{1}$, Seok-Cheol Ko \\ ${ }^{1}$ Division of Electrical, Electronic and Control Engineering and Regional-Industrial Application Research Institute and \\ Institute of IT Convergence Technology, Kongju National University, Republic of Korea \\ ${ }^{2}$ Industry-University Cooperation Foundation and Regional-Industrial Application Research Institute, \\ Kongju National University, Republic of Korea
}

\begin{tabular}{|c|c|}
\hline Article Info & ABSTRACT \\
\hline Article history: & \multirow{11}{*}{$\begin{array}{l}\text { Photovoltaic (PV) generation has been growing dramatically over the last } \\
\text { years and it ranges from small, rooftop-mounted or building integrated } \\
\text { systems, to large utility scale power stations. Especially for rooftop-mounted } \\
\text { PV system, PV modules are serially connected to match with PV inverter } \\
\text { input voltage specification. For serially connected PV system, shading is a } \\
\text { problem since the shaded PV module reduces the output whole string of PV } \\
\text { modules. The excess power from the unshaded PV module is dissipated in } \\
\text { the shaded PV module. In this paper, power dissipation of PV module under } \\
\text { partial shading is analyzed with circuit analysis for series connected PV } \\
\text { modules. The specific current and voltage operating point of the shaded PV } \\
\text { module are analyzed under shading. PSIM simulation tool is used to verify } \\
\text { the power dissipation analysis. When there is no bypass diode and three solar } \\
\text { modules are connected in series, upto } 39.1 \% \text { of the total maximum PV power } \\
\text { is dissipated in the shaded PV module. On the other hand, when the bypass is } \\
\text { attached, 0.3\% of the total maximum power is generated as a loss in the } \\
\text { shaded PV module. The proposed analysis technique of shaded PV module } \\
\text { could be used in PV system performance analysis, especially for maximum } \\
\text { power point tracking (MPPT) performance. }\end{array}$} \\
\hline Received Aug 19, 2020 & \\
\hline Revised Sep 4, 2020 & \\
\hline Accepted Oct 7, 2020 & \\
\hline Keywords: & \\
\hline Hotspot & \\
\hline Partial shading & \\
\hline Power dissipation & \\
\hline PV generation & \\
\hline PV module configuration & \\
\hline PV modules & \\
\hline
\end{tabular}

This is an open access article under the CC BY-SA license.

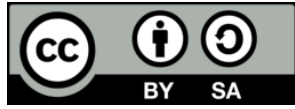

\section{Corresponding Author:}

Byunggyu Yu

Division of Electrical, Electronic and Control Engineering and Institute of IT Convergence Technology

Kongju National University, 1223-24 Cheonan Daero

Seobuk-gu, Cheonan-Si, Chungnam, 330-717, Republic of Korea

Email: bgyuyu@kongju.ac.kr

\section{INTRODUCTION}

Photovoltaic (PV) generation is to convert sunglight directly into electricity by using PV module, which is called as the photovoltaic effect. As PV is one of the increasing important renewalbe energy resources, and it has been widely spread around the world [1,2]. Recently, PV generation has become cost competitive in many regions and it consits of three market segments: residential rooftop [3-5], commercial rooftop [6-7], and ground mount utility scale systems [8-10]. Especially, the number of residential PV system has grown rapidly over the past years $[11,12]$ and sized to provide power that would offset as much of the household load as possible. An averaging around $5 \mathrm{~kW}$ was specified based on the predicted load for a peak day [13]. PV modules are serially connected for residential application by matchng with PV string inverter input voltage specification [14-16]. For serially connected PV system, shading, such a s birds, tree shadows, is a problem since the shaded PV module reduces the output whole string of PV modules [17-19]. The excess power from the unshaded PV module is dissipated in the shaded PV module and it is shown that temperature of the shaded PV module or cell rises as hot spot [20-22]. Until now, research on the shaded PV modules or 
cells has been mainly on the performance of the whole PV system, and there has been little analysis on the circuit and power dissipation of each PV module [23-25].

In this paper, power dissipation of PV module under partial shading is analyzed with circuit analysis for series connected PV modules. Firstly, analysis of PV module power dissipation is presented accroding to the amount of the electric load and circuit operation of each PV module is also introduced. Then, in order to verify the analysis technique, the simulation results are presented.

\section{ANALYSIS OF PV MODULE POWER DISSPATION}

Figure 1 shows the voltage-current characteric curve of PV module by the operating point, which can be classified into three regions. Region 1 is in the power generation mode, which is a desirable condtion to achieve the electric power from the sunlight. However, PV modules are conducted as a power load in Region 2 and 3. The power dissipation in Region 2 and 3 happen under abnormal environmental conditions like partial shading. More specifically, reverse voltage of Region 2 appears in the series-connected PV cells or modules, reverse current of Region 3 appears in the parallel-connected PV cells or modules under partial shading.

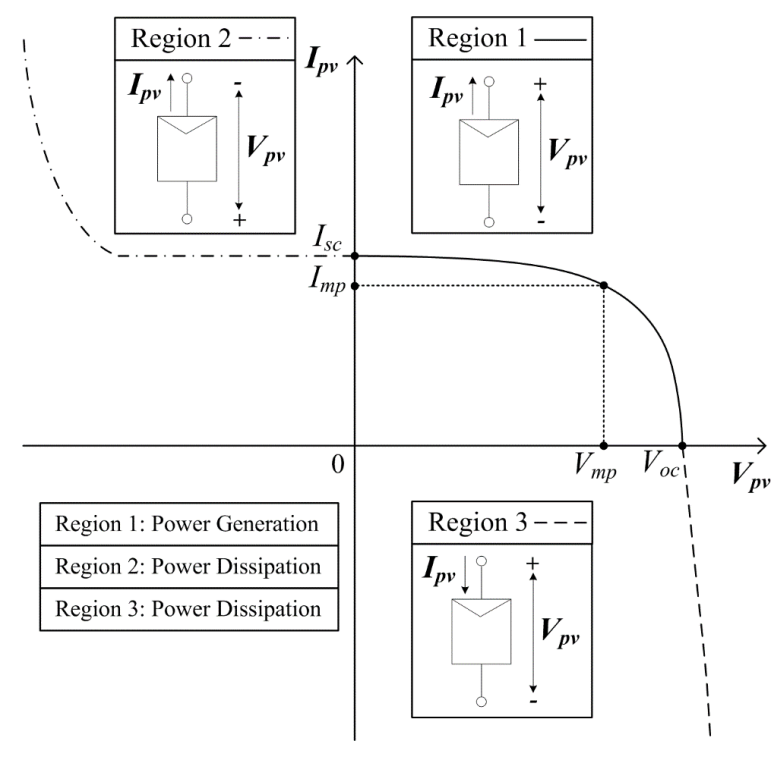

Figure 1. Voltage-current characteristic curve of PV module by the operation point

In this paper, the scope of power dissipation analysis is limited to a series-connected PV modules to focus on bypass diode performance of PV module. In other words, Region 2 of PV module characteristic curve is analyzed under shading condition. In order to analyze the performance of PV module power generation under shading, the following condition is assumed as follows:

Figure 2 shows the PV modules configuration in series to analyze the effect of shading and performance of bypass diodes. Without any shading, $n$ PV modules in series shows voltage-current curve in Figure 3. In the case of $n$ PV modules without bypass didoe under partial shading, the available power to be generated is reduced becasue there is no path for the other current from no shaded (n-1) PV modules. This current makes the reverse voltage of the shaded PV module. Thus, the power is dissipated in the area of Figure 4.

The amount of power dissipation can be quantitized as (1).

$$
P_{\text {diss }}=V_{p v, n t h} \times I_{\text {shading }}
$$

while shading on $n$th PV module, the $n$th PV voltage ranges from $-V_{o p}$ to zero for power dissipation and the $n$th PV current ranges from $I_{\text {shadning,nth }}$ to $I_{s c, n t h}$. The amount of power dissipation is dominated from the other $(n-1)$ PV modules' voltage. Specifically, the power dissipation is maximized at the short circuit condition, $R_{2, \min }$.

In the same way, when n PV modules with bypass diode under partial shading, the generated power can be maximized compared with the previous case, because the bypass diode provides the path for the other current from no shaded (n-1) PV modules. The reverse voltage of the shaed PV module is dominated by the bypass diode threshold voltage, which is normaly $0.7 \mathrm{~V}$. Thus, as shown in Figure 5, the power dissipation is 
reduced dramatically by the low reverse voltage $0.7 \mathrm{~V}$ of the shaded $n$th PV module, compared with the case of no bypass diode. In short, the amount of power dissipation can be quantitized as (2).

$$
P_{\text {diss }}=0.7 \times I_{\text {shading }}
$$

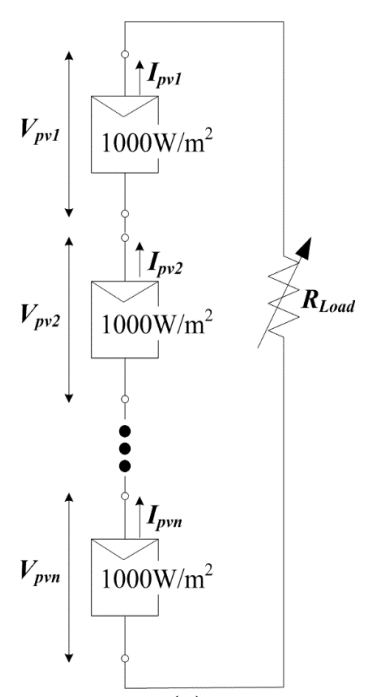

(a)

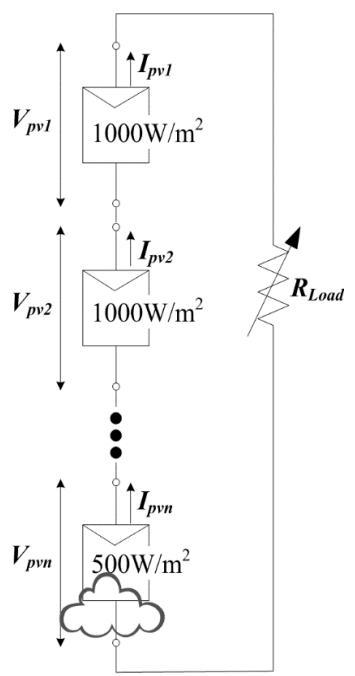

(b)

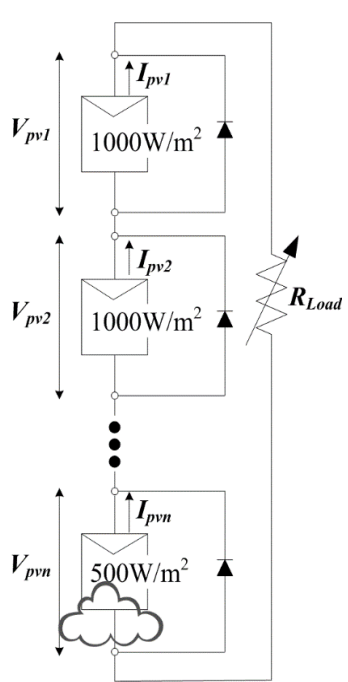

(c)

Figure 2. PV modules configuration in series, (a) case 1: PV connection under no shading, (b) case 2: PV connection without bypass didoes under partial shading,

(c) case 3: PV connection with bypass diodes under partial shading

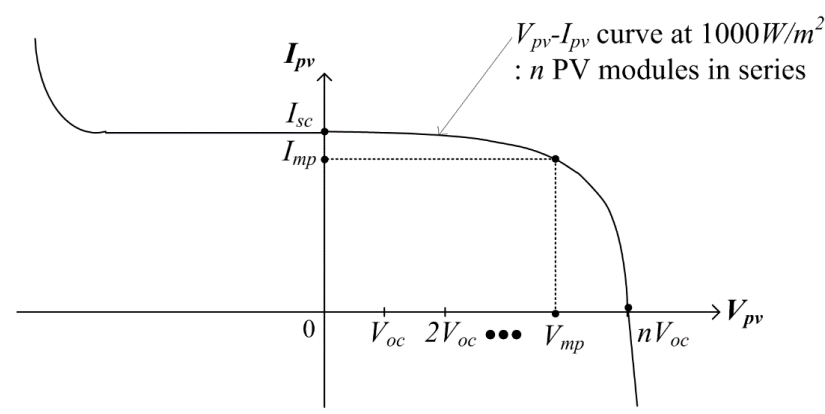

Figure 3. Voltage-current characteristic curve of n PV modules in series under no shading

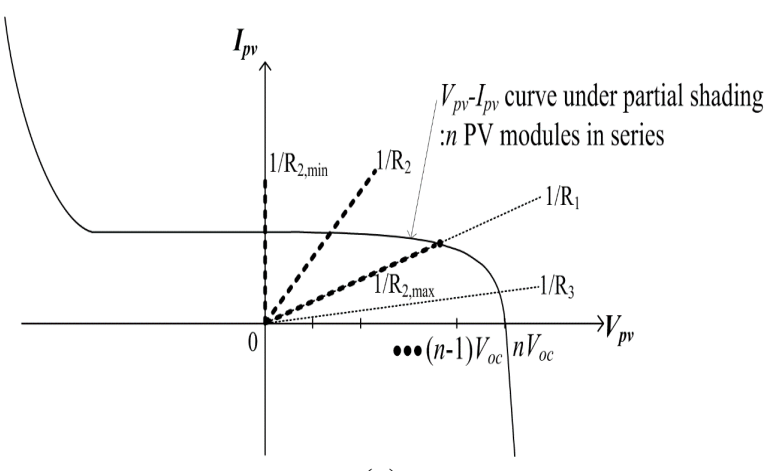

(a)

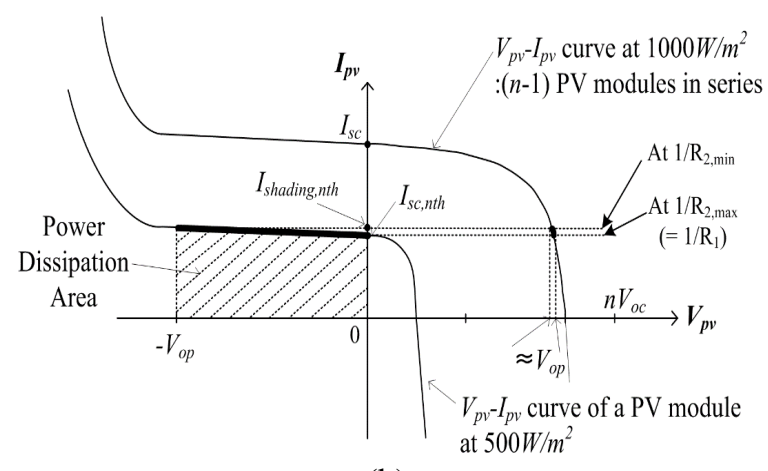

(b)

Figure 4. Voltage-current characteristic curve of n PV modules in series without by pass diodes under partial shading, (a) overall curve of n PV modules, (b) Separate curves of both a PV module under shading and the others under no shading 


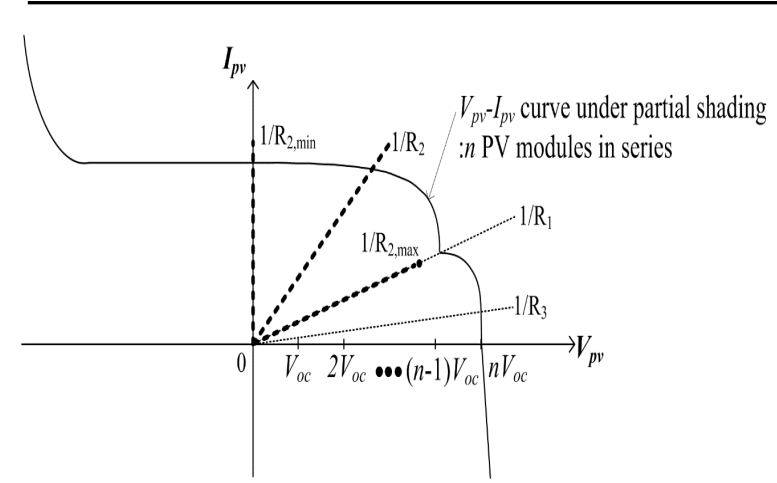

(a)

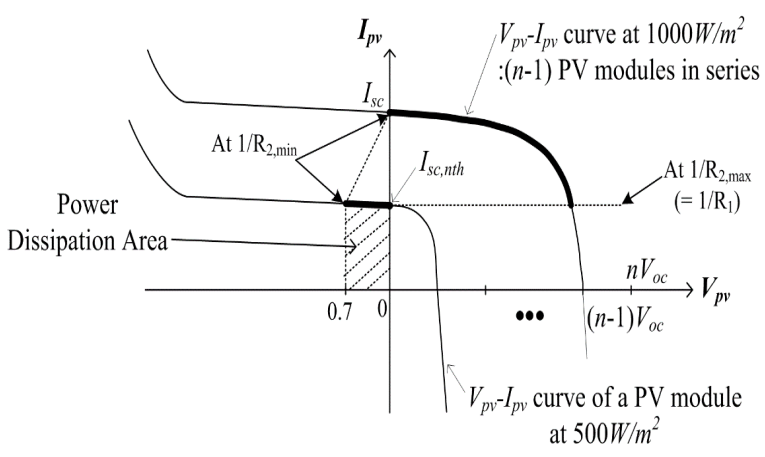

(b)

Figure 5. Voltage-current characteristic curve of $n$ PV modules in series with bypass diodes under partial shading, (a) overall curve of $n$ PV modules, (b) separate curves of both a PV module under shading and the others under no shading

\section{SIMULATION RESULTS}

In order to verify the analysis of power dissipation, three PV modules in series are tested in PSIM simulation software. A commercial PV module datasheet is used for the specification of a PV module to simulate three PV modules in series under partial shading, where maximum power Pmax is $360 \mathrm{~W}$, voltage at maximum power $\mathrm{Vmp}$ is $38 \mathrm{~V}$, current at maximum power is $9.47 \mathrm{~A}$, open circuit voltage $\mathrm{Voc}$ is is $47 \mathrm{~V}$, and short circuit current Isc is $9.72 \mathrm{~A}$.

Three different scenarios as shown in Figure 2 are considered for three PV modules $(n=3)$ in series, in order to verify the analysis of power dissipation. Figure 6 shows characteristic curves of three PV modules in series with regards to shading and bypass diode. For Case 1, there is no distortion of the characteristic curves on PV current and PV power with the nominal values under no shading, and there is only one global maximum power point (MPP). Compared with Case 1, the results of Case 2 and Case 3 under shading are shown in Figure 6. Without bypass diode, the short circuit current for Case 2 is reduced from 9.72 A to 4.861 A becasue there is no path for the other current from no shaded two PV modules. Accordingly, the maximum power with only one global MPP is decrease from $1080 \mathrm{~W}$ to $607 \mathrm{~W}$. The power degradation cause the PV module problem as hot spot problem. Hot spot heating occurs in a PV module under Case 2 while its operating current exceeds the reduced short circuit current.

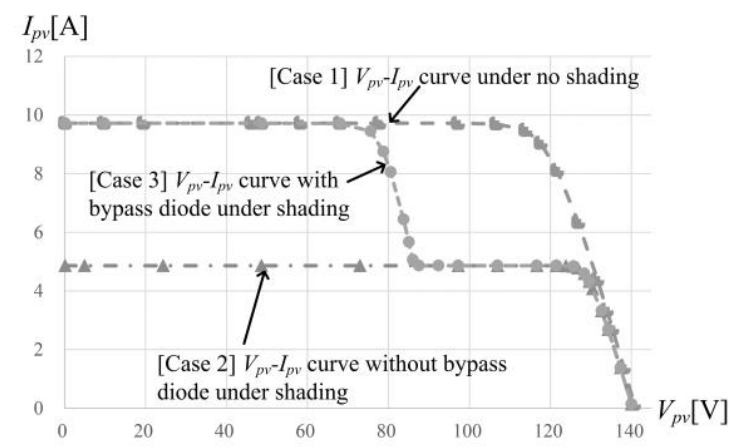

(a)

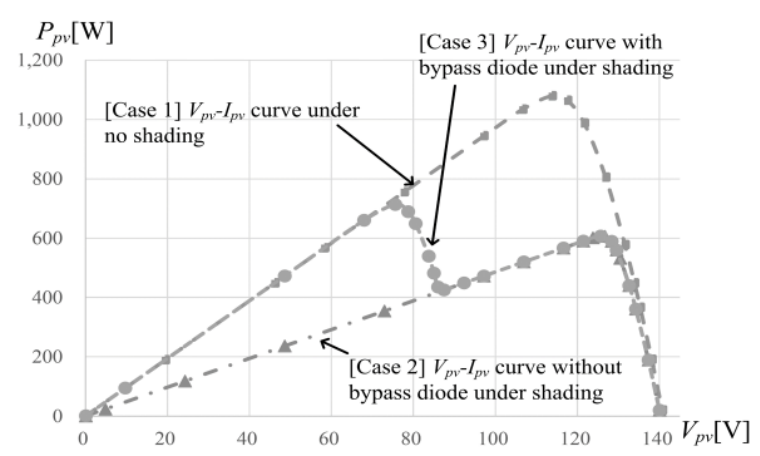

(b)

Figure 6. Characteristic curves of three PV modules in series with regards to shading and bypass diode, (a) voltage-current curve, (b) voltage-power curve

For Case 3, there are two local MPP which are $713 \mathrm{~W}$ and $607 \mathrm{~W}$ because the bypass diode provides the path for the other current from no shaded two PV modules. Since the short circuit current isn't reduced with bypass diode, the hotspot problem of Case 2 doesn't occurs. Specific analysis of power dissipation for the shaded PV module and the other has been conducted. Figure 7 shows the voltage-current characteristic curve of three PV modules in series under partial shading. For Case 2, the voltage across the shaded 3rd PV module ranges from a negative value, $-86.968 \mathrm{~V}$ to a positive value, $46.263 \mathrm{~V}$, as shown in Figure 7 (a). While 
PV voltage is operated at a negative value, the shaded PV module dissipates its power upto $422.751 \mathrm{~W}$ as shown in Figure 8, which can be analyzed by (1). In other words, when there is no bypass diode and three solar modules are connected in series, upto $39 \%$ of the total power generated by the shaded PV module is dissipated, which cause a hotspot.

For Case 3, the negative voltage across the shaded 3rd PV module is limited to $0.7 \mathrm{~V}$ as shown in Figure 7(b), which is the threshold voltage of the bypass diode. The power dissipation of the shaded PV module is limited $3.402 \mathrm{~W}$ as shown in Figure 8. Which means that just $0.3 \%$ power loss of the total power available occurs when the bypass diodes are attached to the PV modules. Therefore, it is concluded that power dissipation can be dramatically reduced by the bypass diode. This result can be applied into a PV module, which is consisted with PV cells and bypass diodes.

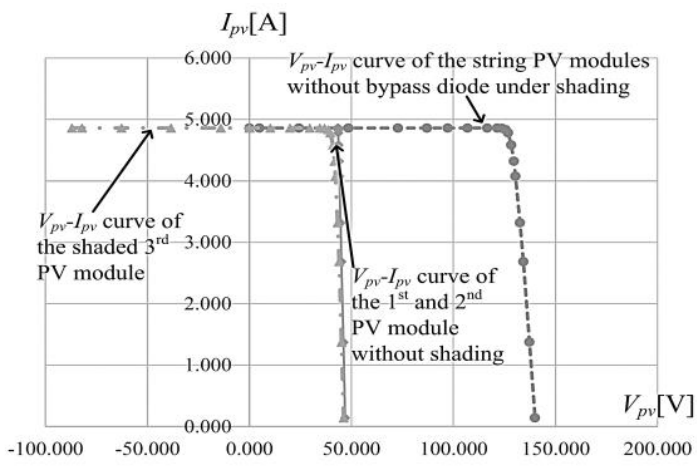

(a)

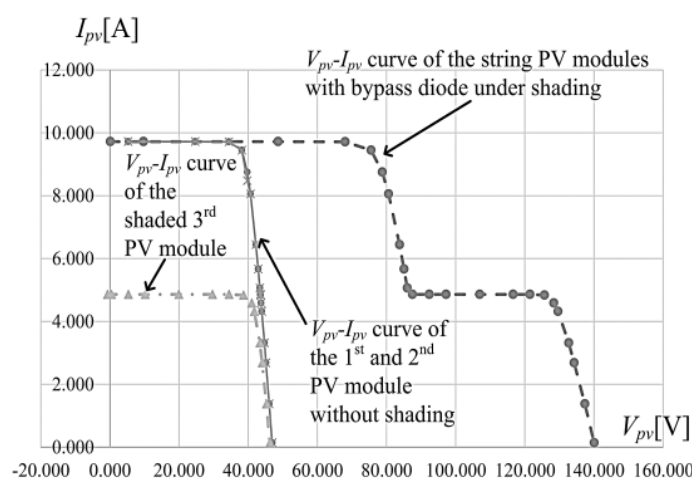

(b)

Figure 7. Voltage-current characteristic curve of three PV modules in series under partial shading, (a) without bypass diode in case 2, (b) with bypass didoe in case 3

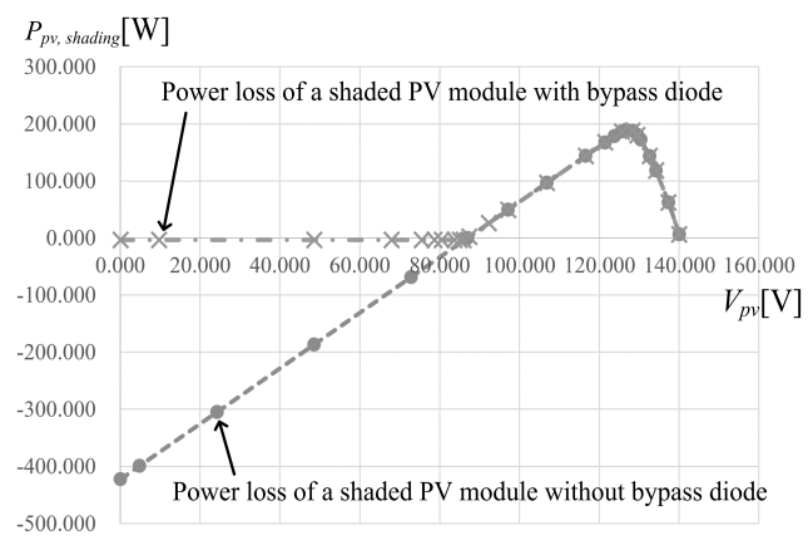

Figure 8. Power loss comparison of shaded PV modules under partial shading with respect to bypass diode

\section{CONCLUSION}

This paper presents the study on the power dissipation of PV module under partial shading with circuit analysis for series connected PV modules. For verify the analysis method, three commercial PV modules in series are considered by PSIM simulation under partial shading. When there is no bypass diode and three solar modules are connected in series, upto 39\% of the total maximum PV power is dissipated in the shaded PV module. On the other hand, when the bypass was attached, $0.3 \%$ of the total maximum power was generated as a loss in the shaded PV module. As a result, the circuit operation of the shaded PV modules was verified as the analysis method to casue so called hot spot. The proposed analysis method on power dissipation of the shaded PV module can be used in the application of PV system performance improvement to prevent hotspot and acheive higher power generation from the shaded PV string. 


\section{ACKNOWLEDGEMENTS}

This work was supported by the 2020 sabbatical year research grant of Kongju National University.

\section{REFERENCES}

[1] S. Eftekharnejad, G. Heydt, and V. Vittal, "Optimal Generation Dispatch With High Penetration of Photovoltaic Generation," IEEE Transactions on Sustainable Energy, vol. 6, no. 3, pp. 1013-1020, 2015.

[2] P. Vithayasrichareon, G. Mills, and I. Macgill, "Impact of Electric Vehicles and Solar PV on Future Generation Portfolio Investment," IEEE Transactions on Sustainable Energy, vol. 6, no. 3, pp. 899-908, 2015.

[3] R. Li and F. Shi, "Control and Optimization of Residential Photovoltaic Power Generation System with High Efficiency Isolated Bidirectional DC-DC Converter," IEEE Access, vol. 7, pp. 116107-116122, 2019.

[4] Y. Sun, et al., "Artificial Neural Network for Control and Grid Integration of Residential Solar Photovoltaic Systems," IEEE Transactions on Sustainable Energy, vol. 8, no. 4, pp. 1484-1495, 2017.

[5] M. Khan, et al., "Autoinspection and Permitting With a PV Utility Interface (PUI) for Residential Plug-and-Play Solar Photovoltaic Unit," IEEE Transactions on Industry Applications, vol. 53, no. 2, pp. 1337-1346, 2017.

[6] S. Martin, et al., "Model to evaluate the system-wide impact of residential and commercial photovoltaic and storage units intended for self-consumption," IET Renewable Power Generation, vol. 13, no. 12, pp. 2111-2122, 2019.

[7] N. Kandsamy, K. Kandasamy, and K. Tseng, "Loss-of-life investigation of EV batteries used as smart energy storage for commercial building-based solar photovoltaic systems," IET Electrical Systems in Transportation, vol. 7, no. 3, pp. 223-229, 2017.

[8] X. Li, et al., "An Unmanned Inspection System for Multiple Defects Detection in Photovoltaic Plants," IEEE Journal of Photovoltaics, vol. 10, no. 2, pp. 568-576, 2020.

[9] A. Sizkouhi, et al., "Automatic Boundary Extraction of Large-Scale Photovoltaic Plants Using a Fully Convolutional Network on Aerial Imagery," IEEE Journal of Photovoltaics, vol. 10, no. 4, pp. 1061-1067, 2020.

[10] T. Kohno, et al., "Fault-Diagnosis Architecture for Large-Scale Photovoltaic Power Plants That Does Not Require Additional Sensors," IEEE Journal of Photovoltaics, vol. 9, no. 3, pp. 780-789, 2019.

[11] D. W. H. Cai, et al., "Impact of residential PV adoption on Retail Electricity Rates," Energy Policy, vol. 62, pp. 830-843, 2013.

[12] Y. Li, W. Gao, and Y. Ruan, "Performance investigation of grid-connected residential PV-battery system focusing on enhancing self-consumption and peak shaving in Kyushu, Japan," Renewable Energy, vol. 127, pp. 514-523, 2018.

[13] D. Chung, et al., "U.S. Photovoltaic prices and cost breakdowns: Q1 2015 benchmarks for residential, commercial, and utility-scale systems," NREL Technical Report, pp. 1-51, 2015.

[14] M. Boztepe, et al, "Global MPPT Scheme for Photovoltaic String Inverters Based on Restricted Voltage Window Search Algorithm," IEEE Transactions on Industrial Electronics, vol. 61, no. 7, pp. 3302-3312, Jul. 2014.

[15] C. Yu, et al., "Modeling and Analysis of Common-Mode Resonance in Multi-Parallel PV String Inverters," IEEE Transactions on Energy Conversion, vol. 34, no. 1, pp. 446-454, 2019.

[16] A. Rana, M. Nasir, and H. Khan, "String level optimisation on grid-tied solar PV systems to reduce partial shading loss," IET Renewable Power Generation, vol. 12, no. 2, pp. 143-148, 2018.

[17] M. Mohamed, A. Diab, and H. Rezk, "Partial shading mitigation of PV systems via different meta-heuristic techniques," Renewable Energy, vol. 130, pp. 1159-1175, 2019.

[18] H. Sah, S. Nayyak, and S. Mishra, "Maximizing the Power Generation of a Partially Shaded PV Array," IEEE Journal of Eemerging and Selected Topic in Power Electronics, vol. 4, no. 2, pp. 626-637, 2016.

[19] O. Bingol and B. Ozkaya, "Analysis and comparison of different PV array configurations under partial shading conditions," Solar Energy, vol. 160, pp. 336-343, Jan. 2018.

[20] K. Kim and P. Krein, "Reexamination of Photovoltaic Hot Spotting to Show Inadequacy of the Bypass Diode," IEEE Journal of Photovoltaics, vol. 5, no. 5, pp. 1435-1441, 2015.

[21] M. Dhuimish, "70\% Decrease of Hot-Spotted Photovoltaic Modules Output Power Loss Using Novel MPPT Algorithm," IEEE Transactions on Circuits and Systems II: Express Briefs, vol. 66, no. 12, pp. 2027-2031, 2019.

[22] D. Winston, "Efficient Output Power Enhancement and Protection Technique for Hot Spotted Solar Photovoltaic Modules," IEEE Transactions on Device and Materials Reliability, vol. 19, no. 4, pp. 664-670, 2019.

[23] J. Ma, et al., "Detection and Assessment of Partial Shading Scenarios on Photovoltaic Strings," IEEE Transactions on Industry Applications, vol. 54, no. 6, pp. 6279-6289, 2018.

[24] S. Mishra, H. Ziar, O. Isabella, and M. Zeman, "Selection Map for PV Module Installation Based on Shading Tolerability and Temperature Coefficient," IEEE Journal of Photovoltaics, vol. 9, no. 3, pp. 872-880, 2019.

[25] J. Ahmed and Z. Salam, "An Improved Method to Predict the Position of Maximum Power Point During Partial Shading for PV Arrays," IEEE Transactions on Industrial Informatics, vol. 11, no. 6, pp. 1378-1387, 2015. 


\section{BIOGRAPHIES OF AUTHORS}
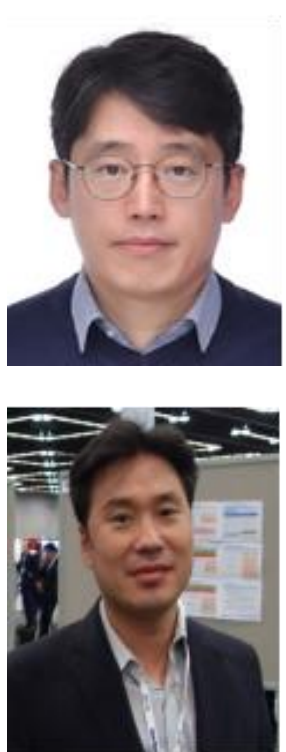

Byunggyu Yu was born in Korea, in 1976. He received the BS and MS degrees in electrical engineering from Pusan University, Korea, in 2000 and from KAIST in 2002, respectively. Since 2002, he had been with the Korea Institute of Energy Research as a Research Fellow. In 2007, he started his RONPAKU doctoral degree program supported by a scholarship from the government of Japan at the Tokyo Polytechnic University, and he received the $\mathrm{PhD}$ degree in electrical engineering in 2010. Since 2012, he has been with Kongju National University as an assistant professor. His research interests include photovoltaic system including the module-integrated converter system and its control algorithm.

Seok-Cheol Ko received his B. S., M. S., and Ph.D. degrees from Chonbuk National Univ., Korea in 1996, 2002, and 2005, respectively. Currently, he is a professor in the IndustryUniversity Cooperation Foundation at Kongju National Univ., Korea. 